\title{
Local adaptation among geographically distant clones of the cosmopolitan freshwater ciliate Meseres corlissi. I. Temperature response
}

\author{
E. Gächter, T. Weisse ${ }^{*}$ \\ Institute for Limnology of the Austrian Academy of Sciences, Mondseestrasse 9, 5310 Mondsee, Austria
}

\begin{abstract}
We used the oligotrich ciliate Meseres corlissi as a model organism to test for local, ecophysiological adaptation among globally distributed, but rare, freshwater ciliates. We investigated the temperature response of $8 \mathrm{M}$. corlissi clones originating from 2 temperate localities in Austria, 1 clone from a (sub)tropical habitat in China and 1 clone from a warm-temperate habitat in Australia. The Austrian clones were isolated either in late autumn to early winter or in summer. The results were compared to those of a previous investigation with a $M$. corlissi isolate from the tropical Dominican Republic. The temperature reaction norm was investigated in laboratory cultures with a small cryptophyte Cryptomonas sp. as food at saturating food levels. Experiments were conducted at temperatures ranging from 7.5 to $30^{\circ} \mathrm{C}$. We measured growth rate, cell volume, and cellular production at each temperature. We found statistically significant differences in the thermal sensitivity of several clones that increased with increasing geographical distance and habitat difference. Overall, the temperature reaction norm (population growth rate vs. temperature) of the temperate Austrian isolates was statistically significantly different from that of the warm-temperate Australian clone, and from the tropical and subtropical isolates from the Dominican Republic and China, respectively. The minimum temperature tolerated by the clones was positively related to the minimum temperature encountered in their natural habitats. Our study provides evidence that freshwater ciliates are physiologically adapted to their respective climatic habitat.
\end{abstract}

KEY WORDS: Local adaptation · Oligotrich ciliates · Temperature response $\cdot$ Intraspecific differences · Meseres corlissi

Resale or republication not permitted without written consent of the publisher

\section{INTRODUCTION}

In contrast to macroorganisms, the extent of biogeography and local adaptation has been poorly studied for aquatic microbes (Dolan 2005, Lowe et al. 2005a,b, Weisse 2006a, Weisse \& Rammer 2006). There is, however, increasing evidence that protist species may have geographically patchy distributions in marine and freshwater (Bulit et al. 2003, 2004, Kim et al. 2004, Katz et al. 2005, Foissner 2006). Freshwater protists with predominant or exclusively asexual reproduction, such as many ciliates and dinoflagellates, have a (multi-) clonal population structure (Kusch 1998, Kusch et al. 2000, Kim et al. 2004, Lowe et al. 2005a), with divergent genotypes and phenotypes. This intraspeci- fic variability may be obvious at the physiological level but can be hidden at the morphological level (Weisse \& Rammer 2006) and even at the molecular level (Lowe et al. 2005b). In particular, temperature adaptation within a nominal species has been revealed to differ between clones, for several planktonic ciliate species (Weisse \& Montagnes 1998, Montagnes \& Weisse 2000, Weisse et al. 2001).

Here we use the oligotrich ciliate Meseres corlissi as a model organism to study the significance of thermal adaptation among geographically distant populations. This ciliate is cosmopolitan, but rare, and therefore likely to form isolated populations. It is usually encountered in $<2 \%$ of samples from suitable habitats (Foissner et al. 2002, Weisse 2004). M. corlissi was described 
from a dried mud sample obtained from an astatic meadow pond in the city of Salzburg, Austria by Petz \& Foissner (1992). M. corlissi is a halterine spirotrich, a close relative of the common Halteria grandinella (Petz \& Foissner 1992, Foissner 2005, Katz et al. 2005). In the past decade, $M$. corlissi has been found on nearly all continents (see Table 1; records other than those listed are known from Namibia, Foissner et al. 2002, Brazil and Venezuela, W. Foissner pers. comm.). Typically, M. corlissi is encountered in flood plains and other dry habitats that are periodically flooded and are exposed to, at least temporarily, relatively high temperatures $\left(>25^{\circ} \mathrm{C}\right)$. As the temperature changes substantially in these environments, and the temperature range is different in temperate and (sub)tropical regions (see Table 1), investigating local ecophysiological adaptation is a useful parameter.

In this study, we investigated the temperature response of 8 clones originating from temperate and subtropical habitats in Austria, China, and Australia and compared these to data from a tropical Meseres corlissi strain from the Dominican Republic (Weisse 2004). All clones exhibited minor divergence $(<1 \%$ sequence dissimilarity) in their small ribosomal subunit RNA sequences (SSU rRNA) and their internal transcribed spacer regions (ITS, $0-2 \%$, M. StrüderKypke et al. unpubl.), and were morphologically almost identical (Foissner 2005, Foissner et al. 2005), suggesting that they are the same species. The goal of this study was to test the null hypothesis that there is no local adaptation to a specific habitat among cosmopolitan freshwater ciliates. Solving this issue is of utmost importance in the context of the ongoing debate about the extent of biogeography and dispersal of free-living microorganisms (Foissner 2006, Weisse 2006a). If there is local adaptation, dispersal must be limited, i.e. the gene pool of each population cannot constantly be swamped by new immigrants, and biogeography of microorganisms is thus likely.

\section{MATERIALS AND METHODS}

Origin of cultures and clones. Two new clones (D2, E4, AU1 and AU5, respectively, in Table 1) of Meseres corlissi were isolated from the type locality (Salzburg, Austria) in November 2002 (Table 1). For the present study, a soil sample ( 0 to $5 \mathrm{~cm}$ ) was taken from the dry bottom of the pond. Clones M3 and M10 were also isolated from this site, but were sampled along a transect (10 m intervals) across the pond in December 2003. Clone KMP2 was isolated from a soil sample $(0$ to $5 \mathrm{~cm}$ ) taken by W. Foissner from a meadow near the railway station Selker of the town of Kefermarkt, Upper Austria. The Austrian 'summer clone' M13 was directly cultured from trophic cells. A water sample was taken from a small puddle at the type locality; single cells were pipetted out of the raw sample and reared with Cryptomonas sp. strain 979/44, as described below.

The Chinese clone CH4W4 originated from the monsoon area of south-east China; samples containing soil and litter of the upper $5 \mathrm{~cm}$ were taken by W. Foissner from the mounted riverbank of the south branch of Zhu Jiang (Perl) River between the villages of Shangzhuang and Xiazhuang. The sampling site is located at the rim of the tropical region of China. Since the minimum monthly winter temperature in this area is $<18^{\circ} \mathrm{C}$, the sampling site falls under the classification humid subtropical climate.

The Australian clone AUA4 was isolated from the upper $5 \mathrm{~cm}$ of samples containing soil and litter from the floodplain of the Murray River. The coordinates

Table 1. Meseres corlissi. Origin of clones and climate characteristics of habitats of origin. Ann. precip.: annual precipitation; Max., Min.: average maximum and minimum monthly temperatures, respectively; Sbg: city of Salzburg; Kfm: Kefermarkt (upper Austria)

\begin{tabular}{|c|c|c|c|c|c|c|c|c|}
\hline \multirow[t]{2}{*}{ Origin } & \multirow[t]{2}{*}{ Clone } & \multirow[t]{2}{*}{ Coordinates } & \multirow{2}{*}{$\begin{array}{l}\text { Sampling } \\
\text { date }\end{array}$} & \multirow[t]{2}{*}{ Climate } & \multirow{2}{*}{$\begin{array}{c}\text { Ann. } \\
\text { precip. (mm) }\end{array}$} & \multicolumn{3}{|c|}{$\longrightarrow$ Avg. $T\left({ }^{\circ} \mathrm{C}\right)$} \\
\hline & & & & & & Annual & Max. & Min. \\
\hline Dominican Republic & DR & $19^{\circ} 47^{\prime} \mathrm{N}, 70^{\circ} 70^{\prime} \mathrm{W}$ & 2001 & Tropical & $962^{\mathrm{a}}$ & $26.0^{\mathrm{a}}$ & $27.9^{\mathrm{a}}$ & $23.7^{\mathrm{a}}$ \\
\hline China & CHI & $23^{\circ} 13^{\prime} \mathrm{N}, 113^{\circ} 30^{\prime} \mathrm{E}$ & Jul 2005 & Subtropical & 1679 & 21.9 & 32.6 & 9.6 \\
\hline Australia & AUS & $36^{\circ} 06^{\prime} \mathrm{S}, 146^{\circ} 92^{\prime} \mathrm{E}$ & Mar 2006 & Warm temperate & 729 & 14.6 & 30.5 & 2.6 \\
\hline Austria (Sbg) & AU1 & $47^{\circ} 47^{\prime} \mathrm{N}, 13^{\circ} 03^{\prime} \mathrm{E}$ & Nov 2002 & Cool temperate & 1201 & 8.4 & 23.5 & -5.8 \\
\hline & AU5 & $47^{\circ} 47^{\prime} \mathrm{N}, 13^{\circ} 03^{\prime} \mathrm{E}$ & Nov 2002 & Cool temperate & 1201 & 8.4 & 23.5 & -5.8 \\
\hline & AU2 & $47^{\circ} 47^{\prime} \mathrm{N}, 13^{\circ} 03^{\prime} \mathrm{E}$ & Dec 2003 & Cool temperate & 1201 & 8.4 & 23.5 & -5.8 \\
\hline & AU3 & $47^{\circ} 47^{\prime} \mathrm{N}, 13^{\circ} 03^{\prime} \mathrm{E}$ & Dec 2003 & Cool temperate & 1201 & 8.4 & 23.5 & -5.8 \\
\hline & AU4 & $47^{\circ} 47^{\prime} \mathrm{N}, 13^{\circ} 03^{\prime} \mathrm{E}$ & Jul 2005 & Cool temperate & 1201 & 8.4 & 23.5 & -5.8 \\
\hline$(\mathrm{Kfm})$ & AU6 & $48^{\circ} 48^{\prime} \mathrm{N}, 15^{\circ} 14^{\prime} \mathrm{E}$ & Sep 2004 & Cool temperate & $869^{\mathrm{b}}$ & $8.8^{\mathrm{b}}$ & $18.6^{\mathrm{b}}$ & $-4^{\mathrm{b}}$ \\
\hline
\end{tabular}

${ }^{a}$ Recorded at Santiago weather station, monthly averages. Precipitation at the elevated sampling site is probably somewhat higher, and mean maximum and minimum monthly temperatures lower than at the weather station, but data are not available ${ }^{b}$ Recorded at the city of Linz weather station at $48.20^{\circ} \mathrm{N}, 15.60^{\circ} \mathrm{E}$ 
and the sampling dates of the various clones used in this investigation are summarized in Table 1, together with some climate characteristics of the respective habitats.

We have given (above) the original clone designations of the individual strains to allow unequivocal identification for future reference. Hereafter, for the sake of simplicity, we use the following codes for the various strains: Austrian clone AU1 (=D2), AU2 (=M3), AU3 (=M10), AU4 (=M13), AU5 (=E4), AU6 (=KMP2); Chinese clone $\mathrm{CHI}(=\mathrm{CH} 4 \mathrm{~W} 4)$; Australian clone AUS (=AUA4); and the strain designation for the clone from the Dominican Republic (DR) remains unchanged.

Eight of the 9 clones used in this investigation were obtained from excysted cells. The original samples were air-dried by W. Foissner for $4 \mathrm{wk}$, and then oversaturated with distilled water, following the 'nonflooded Petri dish method' (Foissner et al. 2002), at room temperature $\left(\sim 21^{\circ} \mathrm{C}\right)$. When Meseres corlissi excysted, it was transferred to 'Eau de Volvic' (French table water; hereafter referred to as mineral water) containing a few crushed wheat grains (Foissner et al. 2005). When a stable population had been established, M. corlissi was further cultured with the small alga Cryptomonas sp., strain 26.80 (Culture Collection of Algae, SAG) or strain 979/44 (UK National Culture Collection of Algae and Protozoa, CCAP), as food organism. The food alga was kept in modified Woods Hole Medium (MWC) (UKNCC 2001) as described previously (Weisse 2004, Weisse \& Stadler 2006). All strains used in this study were maintained at $17.5 \pm$ $0.5^{\circ} \mathrm{C}$ on a $14: 10 \mathrm{~h}$ light:dark cycle at an irradiance of 30 to $50 \mu \mathrm{mol}$ photons $\mathrm{m}^{-2} \mathrm{~s}^{-1}$; $\mathrm{pH}$ in the stock cultures ranged from 7.4 to 8.1 (Weisse \& Stadler 2006).

Clonal cultures of Meseres corlissi were obtained from the enrichment cultures by transferring individual cells into 1 well each of 12 -well tissue culture plates. The wells were filled with 3 to $4 \mathrm{ml}$ of a Cryptomonas and mineral water mixture of $1: 1$. This step was repeated 3 times to ensure the clonal identity of our strains. In the final step a few cells and $5 \mathrm{ml}$ of medium were transferred to culture flasks of $50 \mathrm{ml}$ volume, and the culture volume was gradually increased to approximately $40 \mathrm{ml}$.

In the experiments with clone AU4, 5\% soil extract (SE) were added to the medium (Müller et al. 2006), since preliminary experiments (data not shown) had revealed that this strain requires SE for optimal growth in the culture flasks.

Temperature response experiments: growth rates. Meseres corlissi was taken from exponentially growing cultures, containing Cryptomonas sp. in MWC medium and mineral water. Ciliates were acclimated to the experimental temperatures ranging from 7.5 to $30^{\circ} \mathrm{C}$ in steps of $1.5^{\circ} \mathrm{C}$ change $\mathrm{d}^{-1}$ for 2 to $4 \mathrm{~d}$. The prey cells were acclimated for several hours prior to beginning the experiments.

After the acclimatization period, 10 to $15 \mathrm{ml}$ from the ciliate culture were transferred into sterile $50 \mathrm{ml} \mathrm{cul-}$ ture bottles, containing Cryptomonas sp. at saturating concentrations in MWC medium and mineral water, and adjusted to an initial ciliate abundance of $\sim 25$ cells $\mathrm{ml}^{-1}$. Experimental volume was $50 \mathrm{ml}$. Each experiment was run in triplicate. The acclimation and experiments were conducted at a light intensity of $\sim 50$ to $70 \mu \mathrm{mol}$ photons $\mathrm{m}^{-2}$ under a $14: 10 \mathrm{~h}$ light:dark cycle. Temperatures $>30.5^{\circ} \mathrm{C}$ were not tested, as the food algae Cryptomonas spp. do not tolerate such high temperatures for more than a few hours.

All experiments were conducted at saturating prey levels, which differed between the clones (E. Gächter et al. unpubl. data). Food concentration in the experiments with clones AU1 and AU5 ranged from 120000 to 130000 cells ml $^{-1}$, corresponding to carbon levels of 2.1 to $2.3 \mu \mathrm{g} \mathrm{ml}^{-1}$, assuming $\mathrm{C}(\mathrm{pg})=0.109 \mathrm{~V}\left(\mu \mathrm{m}^{3}\right)^{0.991}$ (Montagnes et al. 1994). For clones AU2, AU3, AU4, AU6 and AUS, the saturating food level was approximately 70000 cells $\mathrm{ml}^{-1}$, corresponding to $1.3 \mu \mathrm{g} \mathrm{C}$ $\mathrm{ml}^{-1}$. Saturating food concentration was lowest for the Chinese clone, ranging from 30000 to 60000 cells ml$^{-1}$, i.e. 0.6 to $1.2 \mu \mathrm{g} \mathrm{C} \mathrm{ml}^{-1}$. The experiments lasted for 36 to $72 \mathrm{~h} ; 5$ to 6 ciliate subsamples were taken during the experiment and fixed with acid Lugol's solution (final concentration $1 \% \mathrm{vol} / \mathrm{vol})$. The experimental duration and the sampling frequency was adjusted to the temperature-dependent growth rates. The ciliate number was enumerated microscopically in a SedgewickRafter chamber of $1 \mathrm{ml}$ volume. Algal abundance and cell volume in each flask was measured during each sampling in unfixed samples with an electronic particle counter (CASY $^{\circledR}$ 1-Model TTC, Schärfe System). Ciliate growth rate $\left(\mu, \mathrm{d}^{-1}\right)$ was determined from the slope of the linear regression of ln Meseres corlissi cell numbers vs. time $(t)$, over the period of exponential increase.

Additional growth experiments were conducted with clones AU2, AU3, AU6, CHI and AUS in 6-well tissue plates of $6 \mathrm{ml}$ volume per well under otherwise identical experimental conditions; 5 to 10 fast swimming cells that were individually picked out of moderately growing cultures, were pipetted into each well at the beginning of the experiments.

Cell volume. Cell volume $(V)$ of ciliate cells was determined from Lugol's fixed material using an inverted microscope and a semi-automatic image analysis system (LUCIA version 4.51 Laboratory Imaging). Samples for volume measurements were taken at the beginning and end of each experiment; the mean cell volume reported was averaged over the experimental duration. Subsamples from 2 or 3 replicates per 
temperature were pooled, and the length and width of 30 ciliates were measured per treatment. Ciliate cell volume was calculated assuming a prolate spheroid shape with circular cross-section. Additionally, cell size of live ciliates resuspended in isotonic solution was measured with an electronic particle counter, as

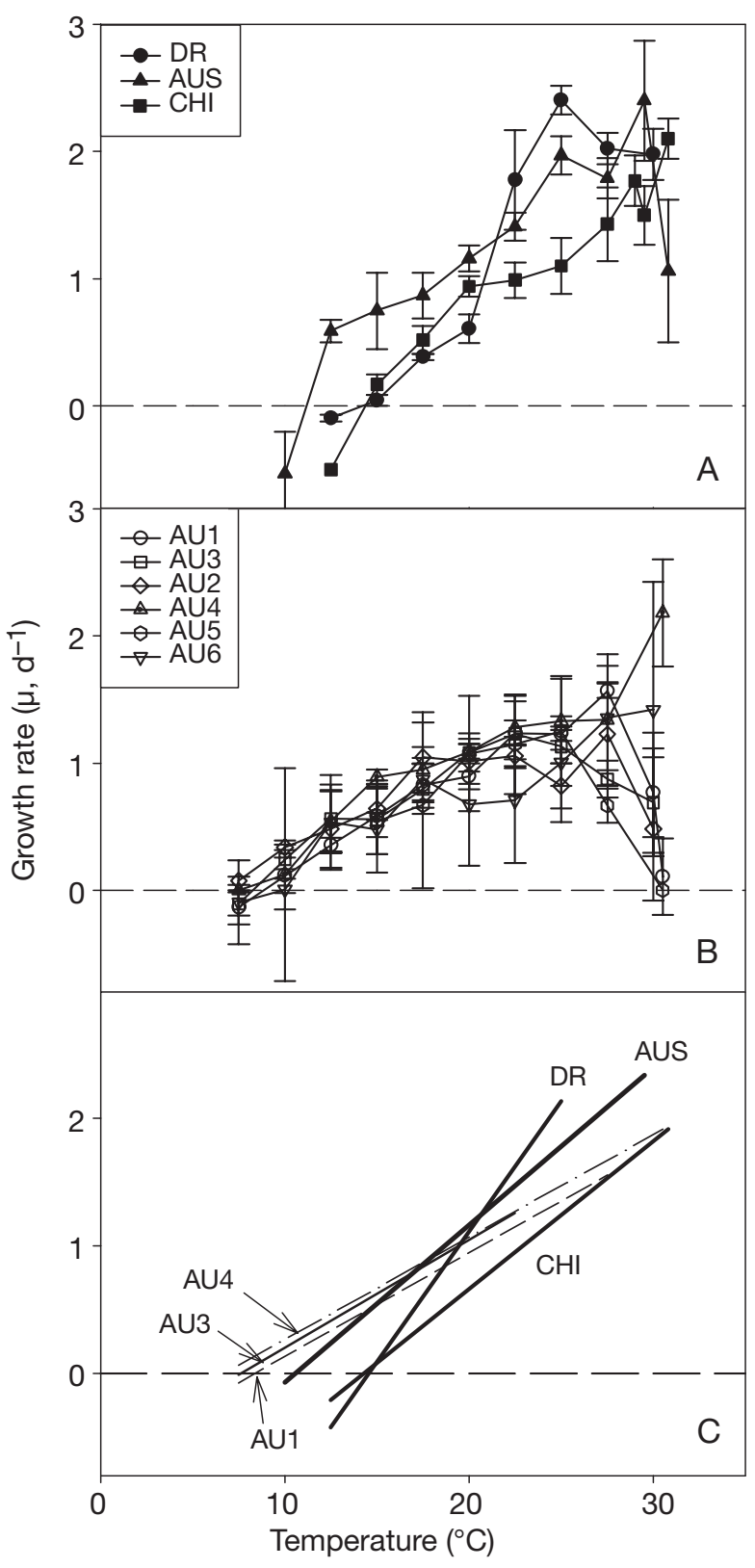

Fig. 1. Meseres corlissi. Growth rate of clones vs. experimental temperature. (A) Strains from the Dominican Republic (DR), Australia (AUS) and China (CHI); (B) 6 Austrian clones from the type locality in Salzburg (AU1 to AU5) and the Mühlviertel region (AU6); (C) linear regressions of $\mu$ vs. $T$ of 6 clones over the temperature range from the minimum temperature tolerated $(\mu=0)$ to the temperature at which $\mu$ peaked. Error bars denote $\pm 1 \mathrm{SD}$ of the mean values described previously for Meseres corlissi (Weisse 2004). Ciliate production $\left(\mathrm{CP}, \mu^{3} \mathrm{~d}^{-1}\right)$ was calculated as the product of growth rate $(\mu)$ and the corresponding cell volume $(V)$.

Statistical analyses. Predictive models were fit to the growth rate vs temperature data to examine responses to temperature for each Meseres corlissi clone and to compare responses between the clones. The complexity (e.g. linear, 2nd, 3rd, or 4th order polynomial) of the model for each clone was determined by sequentially adding parameters; whether the addition of another independent variable significantly improved the fit was then tested by examining whether the constant of the respective variable significantly differed from unity (Zar 1984). The polynomial that yielded the best fit was clone-specifically different. All curves showed a linear increase with increasing temperature from the minimum temperature that was tolerated to the temperature at which $\mu$ peaked. This part of the temperature response was analyzed by leastsquares linear regression for each clone and an overall test for coincidence to test for differences in the slope and $x$-axis intercept of the regressions (Zar 1984, Glantz 1997).

The overall effect of temperature and clone on cell volume was tested by 2-way ANOVA and pairwise multiple comparison procedures (Tukey's test). Clonespecific differences in production rates were analyzed by a Kruskal-Wallis analysis on ranks, as the data did not show equal variance. All statistical analyses were performed with SigmaStat for Windows (Version 2.03, SPSS).

\section{RESULTS}

\section{Growth rates vs. temperature}

The temperature response of 9 strains of Meseres corlissi recorded at saturating food levels revealed some characteristic differences between the isolates (Fig. 1). The tropical and subtropical strains (DR, CHI) needed a minimum temperature of 14 to $15^{\circ} \mathrm{C}$ to increase their cell numbers (Fig. 1A), while all temperate Austrian clones showed positive population growth rates at temperatures $\leq 10^{\circ} \mathrm{C}$ (Fig. 1B). The minimum temperature tolerated by the warm temperate Australian clone (AUS) was intermediate (Fig. 1A). The Austrian and the Australian isolates grew better at the colder temperatures $\left(T \leq 17.5^{\circ} \mathrm{C}\right)$ than the tropical or subtropical strains; the strain from the DR reached significantly higher (1-way ANOVA) growth rates at $T=$ $25^{\circ} \mathrm{C}$ than all other clones.

The statistical model that yielded the best fit for the temperature response curves was clone-specifically 
different. For instance, growth rate of clone AUS reflected a linear response over the entire temperature range. The best fit for growth rates of clone AU1, in contrast, was obtained by a 4 th order polynomial regression. Results for the tropical strain DR and most of the Austrian clones were best described by a quadratic polynomial. The different models obtained for the various clones indicate that the temperature response was clone-specifically different, but they prevented further analysis of the growth rates in relation to temperature of all clones based upon a single predictive model. Population growth rates $(\mu)$ of all strains, however, increased linearly with increasing temperature up to the temperature at which $\mu$ peaked. We used this range, therefore, for the following statistical analysis. The linear regressions calculated for this range illustrated the different temperature-growth response of the various clones (Fig. 1C), i.e. they showed more clearly the minimum temperature at which growth rates were zero $(=x$-axis intercept) and the relative increase with increasing temperature above this critical temperature (= slope of the regressions). For the sake of clarity, we show the regression lines for only 3 of the 6 Austrian clones. The full data set is reported in Table 2. The mean slope of the linear regressions of the 6 Austrian clones was $0.076 \pm 0.008\left(\mathrm{~d}^{-1}{ }^{\circ} \mathrm{C}^{-1}\right)$, whereas the slope of the 3 clones originating from warmer habitats was $>0.11$ $\left(\mathrm{d}^{-1}{ }^{\circ} \mathrm{C}^{-1}\right.$; Table 2$)$. Overall, the temperature response of the tropical strain (DR) and the subtropical clone (CHI) were significantly different from all but one (AU5) of the other isolates investigated (Table 3). The

Table 2. Meseres corlissi. Temperature response range of increase in growth rate $\left(\mu \mathrm{d}^{-1}\right.$ vs. T) of 9 clones. Data correspond to regression lines in Fig. $1 \mathrm{C}$. No data were available for Clone AU5 at temperatures $T<15^{\circ} \mathrm{C}$

\begin{tabular}{|lccc|}
\hline Clone & $\begin{array}{c}\text { Range of linear } \\
\text { Tresponse }\left({ }^{\circ} \mathrm{C}\right)\end{array}$ & $\mathrm{r}^{2}$ & $\begin{array}{c}\text { Linear regression } \\
\text { eq. }\end{array}$ \\
\hline AU1 & $7.5-27.5$ & 0.985 & $\mu=-0.685+0.081 T$ \\
AU2 & $7.5-22.5$ & 0.928 & $\mu=-0.376+0.069 T$ \\
AU3 & $7.5-22.5$ & 0.968 & $\mu=-0.648+0.085 T$ \\
AU4 & $7.5-30.5$ & 0.922 & $\mu=-0.538+0.080 T$ \\
AU5 & $>15-25$ & 0.924 & $\mu=-0.587+0.076 T$ \\
AU6 & $7.5-30$ & 0.901 & $\mu=-0.482+0.063 T$ \\
AUS & $10-29.5$ & 0.916 & $\mu=-1.308+0.124 T$ \\
CHI & $12.5-30.8$ & 0.939 & $\mu=-1.662+0.116 T$ \\
DR & $12.5-25$ & 0.901 & $\mu=-2.982+0.205 T$ \\
\hline
\end{tabular}

warm-temperate Australian clone differed from 5 of the 6 Austrian clones. Among the Austrian clones, AU6 was significantly different from all but one other clone (AU5).

The temperature-dependent growth response of the Meseres corlissi clones was related positively, and non-linearly to the minimum temperature of their natural habitats (Fig. 2). Note firstly that we assumed that the minimum habitat temperature at the sampling site in the DR was $3^{\circ} \mathrm{C}$ lower than given in Table 1 , because the temperature data reported for this area are based upon monthly $24 \mathrm{~h}$ average (monthly averages calculated from daily minimum and maximum temperatures

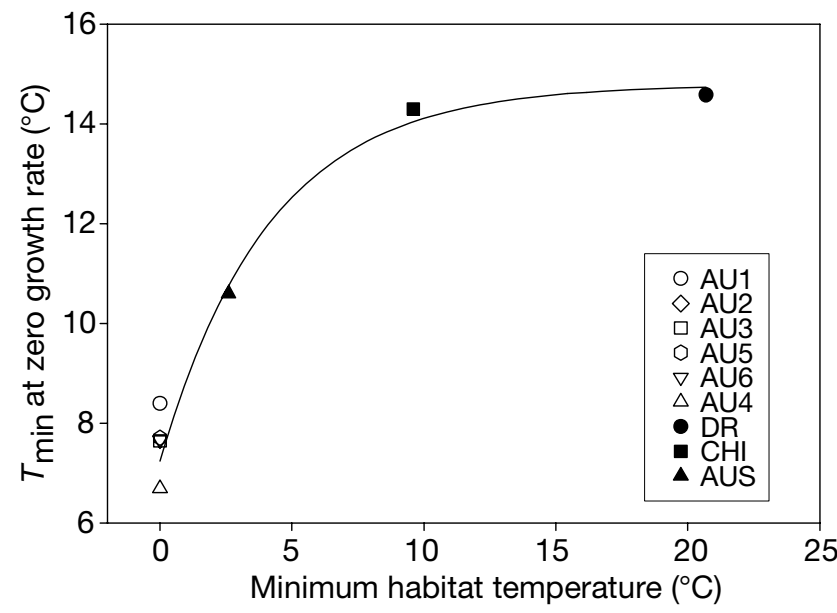

Fig. 2. Meseres corlissi. Minimum temperature tolerated by clones from different geographical regions vs. minimum monthly temperature encountered in their respective habitat. Data were fit to an equation describing exponential rise to the maximum of the form $y=y_{0}+\mathrm{a}\left(1-\mathrm{e}^{(-b \cdot x)}\right)$, where $y_{0}, a$ and $b$ are constants. Open symbols: Austrian clones; filled symbols: non-Austrian strains 


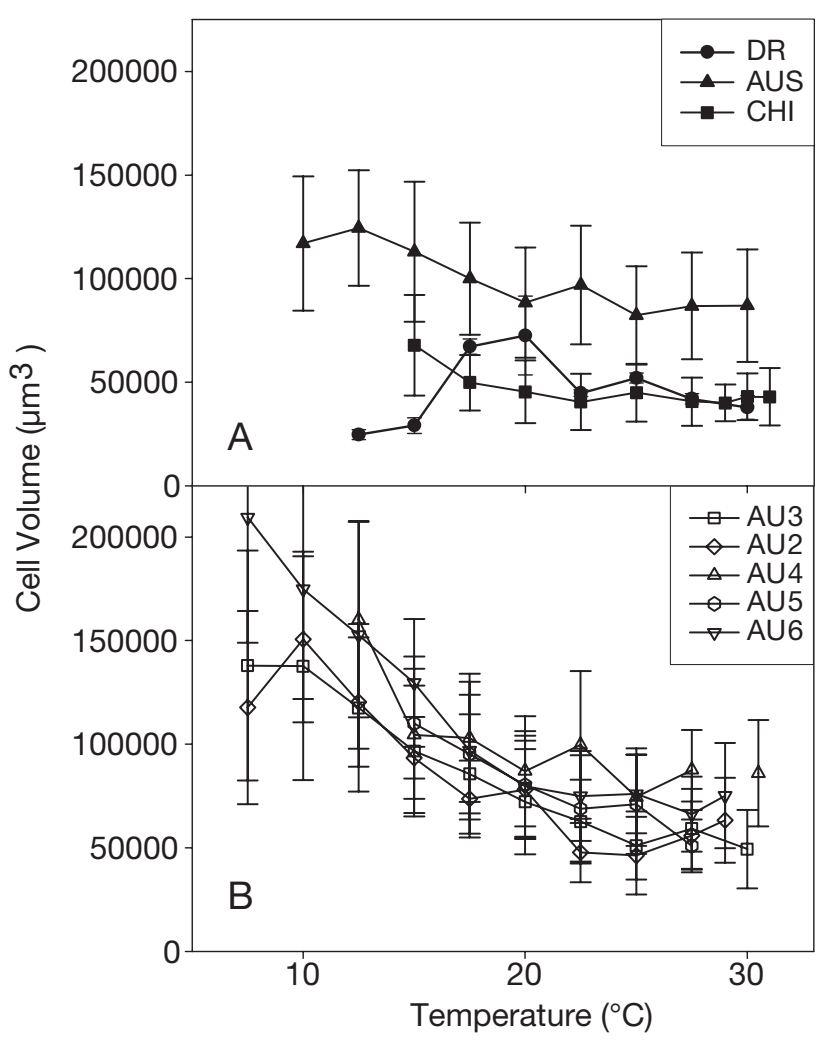

Fig. 3. Meseres corlissi. Cell volume of clones vs. experimental temperature for (A) non-Austrian and (B) Austrian clones

were not available), and secondly, we reduced the minimum habitat temperature to account for the temperature decrease due to the elevation gain at the sampling site (Pico Diego del O'Campo, Foissner et al. 2005) relative to the location of the weather station in the town of Santiago. For the habitats in Austria, we set the minimum habitat temperature to the freezing point. The clones from the warmer regions did not grow at the low temperatures that could be tolerated by the cool temperate Austrian clones.

\section{Cell volume}

Similar to growth rates, temperature and clone significantly affected the cell volume of Meseres corlissi (2-way ANOVA). Austrian clone AU1 was not included in this and the following analysis because we did not measure cell volume at each temperature over its temperature tolerance range. The volume response of the isolate from the DR differed from that of all other clones (Tukey test); its volume increased statistically significantly from 12.5 to $17.5^{\circ} \mathrm{C}$ and then declined linearly at a rate of $-0.04( \pm 0.006, \mathrm{SE})^{\circ} \mathrm{C}^{-1}$ (Fig. $\left.3 \mathrm{~A}\right)$ relative to the volume measured at $20^{\circ} \mathrm{C}$ (Table 4 ). An initial, but statistically insignificant increase in volume with increasing temperature was also observed for the Australian clone (AUS, Fig. 3A) and one of the Austrian clones (AU2, Fig. 3B). Changes in the cell volume of the Australian and the Chinese clones closely paralleled each other between 15 and $30^{\circ} \mathrm{C}$, but the volume of the former was statistically significantly (Tukey test), 2-fold larger (Fig. 3A). The cell volume of all clones but the DR clone declined linearly with increasing temperature from low to moderate temperatures, and then remained constant at warmer temperatures. Except for the DR isolate, with a different volume to temperature response, we related the relative decline to the respective volume measured at $15^{\circ} \mathrm{C}$ (Atkinson et al. 2003). The relative cell volume decrease ${ }^{\circ} \mathrm{C}^{-1}$ of the other clones ranged from 0.03 to $0.08^{\circ} \mathrm{C}^{-1}$ (Table 4 ). For the 5 Austrian clones, the mean decline was $0.06( \pm 0.02)^{\circ} \mathrm{C}^{-1}$.

We compared and averaged the cell volume of those isolates for which data were available within the temperature range 15 to $27.5^{\circ} \mathrm{C}$ (Table 4), i.e. over the range in which growth rates of all clones were positive (cf. Fig. 1A). The 2 smallest clones, the subtropical CHI and the tropical DR, were statistically significantly smaller than most other clones (Table 5). Similarly, the largest clone, AUS, was statistically significantly larger than 4 of the other 7 clones. Among the Austrian clones, AU4 was statistically significantly larger than AU2, while the volume of the other 4 Austrian clones did not differ. The relative temperature effect was lowest for the largest clone, AUS ( $V_{\max }: V_{\min }$ $=1.37)$, and highest for the small clone DR $\left(V_{\max }: V_{\min }\right.$ $=2.49$ ).

Table 4. Meseres corlissi. Temperature effect $\left(T^{\circ} \mathrm{C}\right)$ on cell volume $(V)$ of 8 strains. Slope: slope of linear regression; $V_{\text {avg }}$ : average $\pm \mathrm{SD} V$ at 15 to $27.5^{\circ} \mathrm{C}$

\begin{tabular}{|c|c|c|c|c|c|c|}
\hline Clone & $\begin{array}{c}T \text { range of } \\
\text { linear } \\
V \text { decrease }\end{array}$ & $\begin{array}{l}V\left(\mu \mathrm{m}^{3}\right) \\
\text { at } 15^{\circ} \mathrm{C}\end{array}$ & $\begin{array}{c}\text { Slope } \\
\left(\mu \mathrm{m}^{3}{ }^{\circ} \mathrm{C}^{-1}\right)\end{array}$ & $\begin{array}{c}V \\
\text { decrease } \\
\left(\% \mathrm{C}^{-1}\right)\end{array}$ & $r^{2}$ & $\begin{array}{c}V_{\text {avg }} \\
\left(\mu \mathrm{m}^{3}\right)\end{array}$ \\
\hline AU2 & $10-25$ & 104109 & -6768 & 6.50 & 0.925 & $65860 \pm 18880$ \\
\hline AU3 & $10-25$ & 103176 & -5627 & 5.45 & 0.978 & $71290 \pm 17200$ \\
\hline AU4 & $12.5-25$ & 124748 & -8845 & 7.09 & 0.796 & $92740 \pm 18880$ \\
\hline AU5 & $15-27.5$ & 106460 & -4329 & 4.07 & 0.944 & $79400 \pm 20840$ \\
\hline AU6 & $7.5-2$ & 127604 & -10346 & 8.11 & 0.993 & $87250 \pm 23050$ \\
\hline AUS & $15-22.5$ & 112450 & -3097 & 2.75 & 0.857 & $94570 \pm 11170$ \\
\hline $\mathrm{CHI}$ & $12.5-25$ & 63874 & -3459 & 5.42 & 0.876 & $48220 \pm 10220$ \\
\hline DR & $17.5-30$ & $62640^{\mathrm{a}}$ & -2643 & $4.22^{\mathrm{a}}$ & 0.762 & $51280 \pm 16280$ \\
\hline
\end{tabular}


Table 5. Meseres corlissi. Differences in the volume to temperature response of 8 clones over temperature range 15 to $27.5^{\circ} \mathrm{C}$. Results of 2-way ANOVA and Tukey's test. ns: not significant; ${ }^{*} p<0.05,{ }^{* *} p<0.01,{ }^{* * *} p<0.001$

\begin{tabular}{|ccccccccc|}
\hline Clone & AU2 & AU3 & AU4 & AU5 & AU6 & DR & CHI & AUS \\
\hline AU2 & - & ns & ${ }^{* *}$ & ns & ns & ns & ns & $* *$ \\
AU3 & ns & - & ns & ns & ns & ns & ${ }^{* *}$ & $*$ \\
AU4 & ${ }^{* *}$ & ns & - & ns & ns & ${ }^{* *}$ & $* * *$ & ns \\
AU5 & ns & ns & ns & - & ns & ${ }^{* *}$ & ${ }^{* * *}$ & ns \\
AU6 & ns & ns & ns & ns & - & ${ }^{* * *}$ & ${ }^{* * *}$ & ns \\
DR & ns & ns & ${ }^{* *}$ & ${ }^{* * *}$ & ${ }^{* * *}$ & - & ns & ${ }^{* * *}$ \\
CHI & ns & ${ }^{* *}$ & ${ }^{* * *}$ & ${ }^{* *}$ & & ns & - & ${ }^{* * *}$ \\
\hline
\end{tabular}

\section{Production rates}

Cellular production rates (CP) of Meseres corlissi, which are the product of growth rate and cell volume, differed in relation to temperature. In the strains from warmer climates, changes in $\mathrm{CP}$ with temperature (Fig. 4A) followed those of growth rates (Fig. 1A), since the relative temperature effect on cell volume was less pronounced than in the Austrian clones (see above and Fig. 3). The temperature effect on $\mathrm{CP}$ of the latter was comparatively small (Fig. 4B), because growth rates of the Austrian clones generally increased with increasing

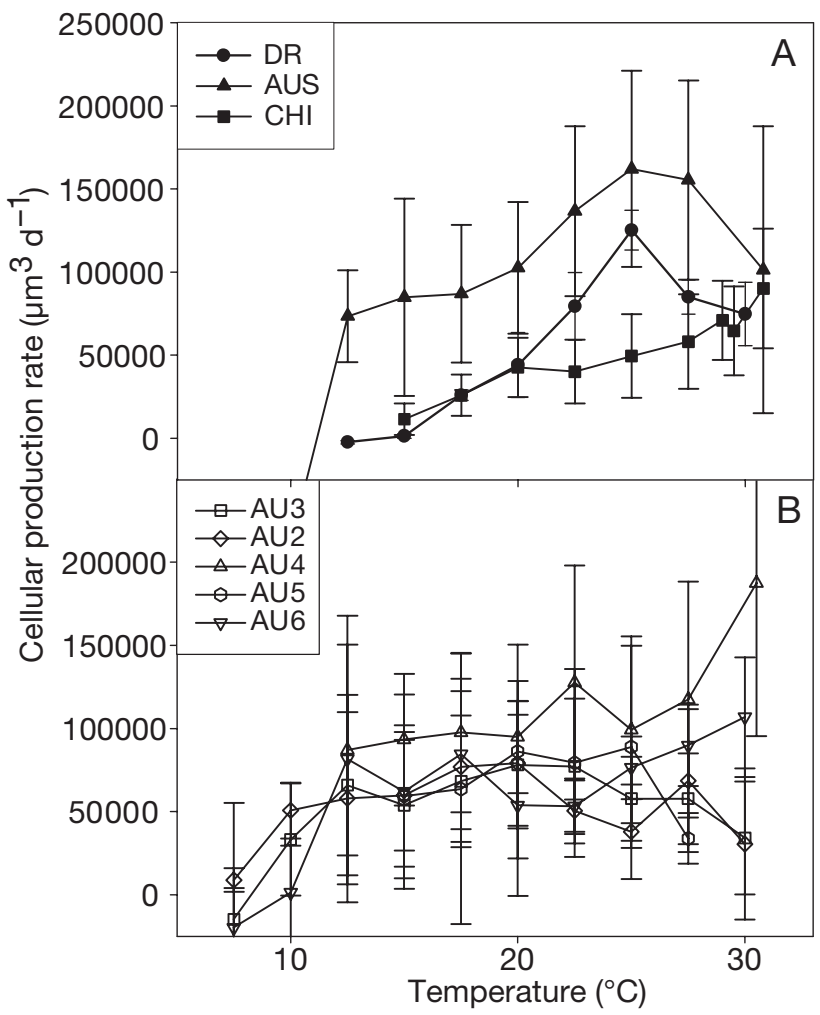

Fig. 4. Meseres corlissi. Production rate of clones vs. experimental temperature for (A) non-Austrian and (B) Austrian clones temperature (Fig. 1B), while their cell volume declined (Fig. 3B). Within the temperature range 15 to $27.5^{\circ} \mathrm{C}$, at which production estimates were available for all clones, the mean $\mathrm{CP}$ of the Australian clone (121400 \pm $34450 \mu^{3} \mathrm{~d}^{-1}$ ) and the Austrian summer clone AU4 $\left(104950 \pm 14100 \mu^{3}\right.$ $\mathrm{d}^{-1}$ ) were both significantly higher (Kruskal-Wallis 1-way ANOVA on ranks and Dunn's test) than those of the Chinese clone $\left(38000 \pm 16800 \mu^{3} \mathrm{~d}^{-1}\right)$. Production rates of all other clones did not differ significantly from each other.

\section{DISCUSSION}

This study continued previous work on the ecophysiology (Weisse 2004, Müller et al. 2006) and morphology (Petz \& Foissner 1992, Foissner 2005, Foissner et al. 2005, 2006) of the rare oligotrich ciliate Meseres corlissi. We found statistically significant physiological (growth rates) and morphological (cell volume) differences between clones originating from geographically distant habitats. Those differences cannot be explained by phenotypic flexibility or acclimatization to specific laboratory conditions, because we had kept stock cultures of all our clones under identical laboratory conditions for many ( $>200$ ) generations prior to beginning the experiments. Our conclusions are conservative, because none of our statistical methods used the full information of the respective data sets. This is because neither the growth nor the volume response to temperature of all clones could be described by a single descriptive model that would account for all differences observed. For the growth response, we did not consider differences measured at the highest temperatures tolerated. Our analysis of the thermal effect on volume was limited to the range over which data were available for all clones. If growth rates were negative, we could not measure cell volume with any statistical reliability. In particular, the information at the lowest temperatures tested, at which the cell volume differed most among the clones (Fig. 3), was not included in our ANOVA. We could not use an ANCOVA to test for significant differences in the slopes and elevation of the regression lines (Zar 1984) calculated for the linear portion of the volume response, because the temperature range of the linear decrease in volume differed too much between clones (Table 4). For the comparison of cellular production, we had to use a non-parametric statistical test with somewhat limited power. Accordingly, the 'true' differences among the clones are, most likely, greater than reported in Tables $3 \& 5$. 
In spite of these caveats, we can reject our null hypothesis, i.e. that there is no local adaptation among cosmopolitan freshwater ciliates. The most important result of our study is that the growth response of the Meseres corlissi clones was related positively to the (minimum) temperature of their natural habitats. Similar to our results, a correspondence between growth rate and habitat temperature was reported recently for freshwater bacteria with identical SSU rRNA genes (Hahn \& Pöckl 2005). Intraspecific adaptation to temperature is also known for Daphnia (De Meester 1996, De Meester et al. 2006, Weisse 2006b) and copepods; for the latter, faster growth rates at cooler temperatures were found for northern populations within a North American estuarine harpactoid copepod species (Lonsdale \& Levinton 1985). The existing evidence for habitat-specific temperature adaptation of freshwater ciliates is controversial. It has long been known that different isolates of Paramecium aurelia show genetically fixed adaptations to different temperature (Lee \& Fenchel 1972). The same authors reported latitudinal differences in the temperature tolerance range for 3 Euplotes species. S. Krenek et al. (unpubl. data) found statistically significantly different growth rates vs. temperature between 3 clonal lineages of $P$. caudatum isolated from northern, central and southern Europe, but the temperature response was not related to the geographical origin of the clones. A clonal isolate of the common prostome ciliate Balanion planctonicum from prealpine Lake Mondsee tolerated higher water temperature than another clone isolated from the slightly colder prealpine Lake Constance; however, the opposite was true for 2 clonal lineages of Urotricha furcata, another common prostome species isolated from the same lakes (Weisse et al. 2001).

For Meseres corlissi, we found only minor differences in the temperature response between the 5 clones isolated from the type locality in the city of Salzburg. The 6th Austrian clone (AU6), originating from a site approximately $130 \mathrm{~km}$ NE of Salzburg, was statistically significantly different from 4 of the 5 Salzburg clones, and the temperature response of the non-Austrian clones differed from each other and from that of the Austrian clones (Table 3). The response to $\mathrm{pH}$ of $M$. corlissi, which was investigated in our laboratory independently from the present study ( $T$. Weisse et al. unpubl. data), confirmed the present results. There was no or only a minor difference in the $\mathrm{pH}$ response between the clones isolated from the type locality, while T. Weisse et al. (unpubl. data) reported statistically significant differences between the Austrian clones from Salzburg and Upper Austria, and highly significant differences between the Austrian clones and the strains from China and Australia. Accordingly, both studies demonstrated that clonal dif- ferences increase with increasing geographic distance, suggesting limited dispersal and/or limited reproductive success of invaders. These findings contrast with recent results obtained with marine diatoms (Rynearson \& Armbrust 2000, 2004) and common freshwater ciliates (Weisse \& Rammer 2006); both taxa revealed pronounced physiological variation of sympatric clones. We speculate that a lower rate of dispersal of the rare $M$. corlissi, relative to the above common protist species, may facilitate temperature adaptation to a given habitat through directional selection. In contrast to oceanic environments and large lakes, the habitats in which $M$. corlissi thrives are typically short-lived and shallow, without vertical gradients in major environmental parameters. The lack of heterogeneity over temporal or spatial scales in a given $M$. corlissi habitat is in sharp contrast to the heterogeneity observed across geographically distant localities from different continents. This may explain why the genetic and physiological diversity of $M$. corlissi is low in a particular environment such as a meadow pond.

With the possible exception of the isolate from the DR, none of the Meseres corlissi clones grew at the minimum temperatures encountered in their natural habitat. This does not preclude that $M$. corlissi survives in the encysted stage at low temperatures. For the isolate from the DR, low temperature $\left(<20^{\circ} \mathrm{C}\right)$ was the primary trigger for encystment (Weisse 2004), while temperature was rather unimportant for cyst formation of Austrian clones AU3 and AU5 (Müller et al. 2006). For the Australian and the Chinese clones investigated in this study, we did not observe an unequivocal temperature signal for cyst formation (authors' unpubl. obs.).

The finding that growth rates of Meseres corlissi increased linearly with increasing temperature up to the temperature at which $\mu$ peaked confirms the recent conclusion that growth rate of ciliates and other autotrophic and heterotrophic protists usually responds linearly, not exponentially, to temperature (Montagnes et al. 2003, Weisse 2006b). The volume response to temperature we observed suggests that $M$. corlissi is a thermally sensitive species relative to other aquatic protists (Atkinson et al. 2003), and that this thermal sensitivity may be intraspecifically different. Our data confirm the general shape of the temperature response in ectotherms, with a linear decrease in cell volume in the thermal range normally encountered by the populations. The thermal sensitivity of all $M$. corlissi clones was, however, higher than the mean thermal sensitivity $\left(2.5 \%\right.$ decrease $\left.{ }^{\circ} \mathrm{C}^{-1}\right)$ reported by Atkinson et al. (2003) from a literature review of 65 data sets on various protist taxa. When only those 20 data sets that yielded statistically significant linear negative regressions between volume and temperature were used, the mean thermal sensitivity was higher $\left(-4 \%{ }^{\circ} \mathrm{C}^{-1}\right)$, which 
is identical to the mean thermal sensitivity of our nonAustrian M. corlissi strains (Table 4). The negative temperature effect on cell volume was, however, higher in all 6 cool temperate $M$. corlissi clones investigated in this study (Table 4). In contrast, the warm temperate Australian clone, which may encounter an even larger range of habitat temperature than the cool temperate Austrian clones, showed the least thermal sensitivity of all $8 \mathrm{M}$. corlissi clones tested. Further data are needed to reveal if there is any relation between the range of the habitat temperature and the relative thermal sensitivity of aquatic protists.

In conclusion, our results support the earlier conjecture that local adaptation is common among cosmopolitan freshwater ciliates (Weisse 2002, 2003, 2006b, Müller et al. 2006, Weisse \& Rammer 2006). The implications for the ongoing debate about protistan biogeography and the most adequate species concept (reviewed by Foissner 2006 and Weisse 2006a) are obvious; the (morpho-)species concept hitherto used by most taxonomists and ecologists does not reveal the true biodiversity of ciliates and other aquatic protists. Which factors (e.g. limited dispersal, failing success of invaders, locally differing rate of benefitial mutations, infrequent or complete lack of sexual reproduction) are primarily responsible for local adaptation is difficult to decide, because differences caused by longrange geographic distance and habitat usually interact, in particular with respect to temperature. Further, we do not know the pecularities of the abiotic and biotic environment at the sampling sites outside Austria. Similarly, which genes are responsible for the local temperature adaptation is still unknown. The physiological differences of $M$. corlissi do not show up in conserved genes such as the small ribosomal subunit (M. Strüder-Kypke et al. unpubl. data). Recently, differential expression of similar $\mathrm{Na}^{+} / \mathrm{K}^{+}$ ATPase genes (mRNA sequences) could be linked to salinity tolerance of 3 Brachionus plicatilis (Rotifera) sibling species (Lowe et al. 2005b). The quest for adapative mutations of freshwater protists is difficult for complex physiological responses such as growth rates (Weisse \& Rammer 2006), but may be stimulated in the near future, when more genomes of various protist species will be available.

Acknowledgements. We are grateful to W. Foissner for providing most of the Meseres corlissi raw cultures, for verification of the species identity, and for continued discussions and support during this project. The statistical advice by F. Firneis is gratefully acknowledged. We thank U. Scheffel for her technical assistance, in particular for maintaining ciliate stock cultures. D. J. S. Montagnes, H. Müller, M. W. Hahn, and 3 anonymous reviewers provided fruitful comments on an earlier version of this manuscript. This study was supported by the Austrian Science Foundation (FWF, project P16796-B06).

\section{LITERATURE CITED}

Atkinson D, Ciotti BJ, Montagnes DJS (2003) Protists decrease in size linearly with temperature: ca. $2.5 \%{ }^{\circ} \mathrm{C}^{-1}$. Proc R Soc Lond B 270:2605-2611

Bulit C, Díaz-Avalos C, Signoret M, Montagnes DJS (2003) Spatial structure of planktonic ciliate patches in a tropical lagoon: an application of geostatical methods. Aquat Microb Ecol 30:185-196

Bulit C, Díaz-Ávalos C, Montagnes DJS (2004) Assessing spatial and temporal patchiness of the autotrophic ciliate Myrionecta rubra: a case study in a coastal lagoon. Mar Ecol Prog Ser 268:55-67

De Meester L (1996) Local genetic differentiation and adaptation in freshwater zooplankton populations: patterns and processes. Ecoscience 3:385-399

De Meester L, Vanoverbeke J, De Gelas K, Ortells K, Spaak P (2006) Genetic structure of cyclic parthenogenetic zooplankton populations - a conceptual framework. Arch Hydrobiol (in press)

Dolan JR (2005) Biogeography of aquatic microbes. Aquat Microb Ecol 41:39-48

Foissner W (2005) The unusual, lepidosome-coated resting cyst of Meseres Corlissi (Ciliophora: Oligotrichea): transmission electron microscopy and phylogeny. Acta Protozool 44:217-230

Foissner W (2006) Biogeography and dispersal of microorganisms: a review emphasizing protists. Acta Protozool 45: $111-136$

Foissner W, Agatha S, Berger H (2002) Soil ciliates (Protozoa, Ciliophora) from Namibia (southwest Africa), with emphasis on two contrasting environments, the Etosha region and the Namib Desert. Denisia 5:1-1459

Foissner W, Müller H, Weisse T (2005) The unusual, lepidosome-coated resting cyst of Meseres corlissi (Ciliophora: Oligotrichea): light and scanning electron microscopy, cytochemistry. Acta Protozool 44:201-215

Foissner W, Pichler M, Al-Rasheid K, Weisse T (2006) The unusual, lepidosome-coated resting cyst of Meseres corlissi (Ciliophora: Oligotrichea): encystment and genesis and release of the lepidosomes. Acta Protozool 45 (in press)

Glantz SA (1997) Primer of biostatistics. McGraw-Hill, New York

Hahn MW, Pöckl M (2005) Ecotypes of planktonic Actinobacteria with identical 16S rRNA genes adapted to thermal niches in temperate, subtropical, and tropical freshwater habitats. Appl Environ Microbiol 71:766-773

Katz LA, McManus GB, Snoeyenbos-West OLO, Griffin A, Pirog K, Costas B, Foissner W (2005) Reframing the 'everything is everywhere' debate: evidence for high gene flow and diversity in ciliate morphospecies. Aquat Microb Ecol 41:55-65

Kim E, Wilcox L, Graham L, Graham J (2004) Genetically distinct populations of the dinoflagellate Peridinium limbatum in neighboring northern Wisconsin Lakes. Microb Ecol 48:521-527

Kusch J (1998) Local and temporal distribution of different genotypes of pond-dwelling Stentor coeruleus. Protist 149:147-154

Kusch J, Welter H, Stremmel M, Schmidt HJ (2000) Genetic diversity in populations of a freshwater ciliate. Hydrobiologia 431:185-192

Lee CC, Fenchel T (1972) Studies on ciliates associated with sea ice from Antarctica. II. Temperature responses and tolerances in ciliates from Antarctic, temperate and tropical habitats. Arch Protistenkd 114:237-244 
Lonsdale DJ, Levinton JS (1985) Latitudinal differentiation in copepod growth: an adaptation to temperature. Ecology 66:1397-1407

Lowe CD, Day A, Kemp SJ, Montagnes DJS (2005a) There are high levels of functional and genetic diversity in Oxyrrhis marina. J Eukaryot Microbiol 52:250-257

Lowe CD, Kemp SJ, Montagnes DJS (2005b) An interdisciplinary approach to assess the functional diversity of freeliving microscopic eukaryotes. Aquat Microb Ecol 41: $67-77$

Montagnes DJS, Weisse T (2000) Fluctuating temperatures affect growth and production rates of planktonic ciliates. Aquat Microb Ecol 21:97-102

Montagnes DJS, Berges JA, Harrison PJ, Taylor FJR (1994) Estimating carbon, nitrogen, protein, and chlorophyll a from volume in marine phytoplankton. Limnol Oceanogr 39:1044-1060

Montagnes DJS, Kimmance SA, Atkinson D (2003) Using $Q_{10}$ : Can growth rates increase linearly with temperature? Aquat Microb Ecol 32:307-313

Müller H, Foissner W, Weisse T (2006) The role of soil in the life cycle of Meseres corlissi (Ciliophora: Oligotrichea): experiments with two clonal strains from the type locality, an astatic meadow pond. Aquat Microb Ecol 42:199-208

Petz W, Foissner W (1992) Morphology and morphogenesis of Strobilidium caudatum (Fromentel), Meseres corlissi n. sp., Halteria grandinella (Müller), and Strombidium rehwaldi $\mathrm{n}$ sp., and a proposed phylogenetic system for oligotrich ciliates (Protozoa, Ciliophora). J Protozool 39: 159-176

Rynearson TA, Armbrust EV (2000) DNA fingerprinting reveals extensive genetic diversity in a field population of the centric diatom Ditylum brightwellii. Limnol Oceanogr 45:1329-1340

Rynearson TA, Armbrust EV (2004) Genetic differentiation among populations of the planktonic marine diatom Ditylum brightwelli (Bacillariophyceae). J Phycol 40:34-43

UKNCC (2001) List of algae and protozoa. UK National

Editorial responsibility: Robert Sanders,

Philadelphia, Pennsylvania, USA
Culture Collection, Windermere/Oban

Weisse T (2002) The significance of inter- and intraspecific variation in bacterivorous and herbivorous protists. Antonie Leeuwenhoek 81:327-341

Weisse T (2003) Pelagic microbes - Protozoa and the microbial food web. In: O'Sullivan P, Reynolds CS (eds) The lakes handbook, Vol 1. Blackwell Science, Oxford, p 417-460

Weisse T (2004) Meseres corlissi: a rare oligotrich ciliate adapted to warm water and temporary habitats. Aquat Microb Ecol 37:75-83

Weisse T (2006a) Biodiversity of freshwater microorganisms - achievements, problems, and perspectives. In: Gliwicz ZM, Mazurkiewicz-Boron G, Rouen K (eds) Reviewing European freshwater sciences, 2005. Pol J Ecol (in press)

Weisse T (2006b) Freshwater ciliates as ecophysiological model organisms - lessons from Daphnia, major achievements, and future perspectives. Arch Hydrobiol 167: $371-402$

Weisse T, Montagnes DJS (1998) Effect of temperature on inter- and intraspecific isolates of Urotricha (Prostomatida, Ciliophora). Aquat Microb Ecol 15:285-291

Weisse T, Rammer S (2006) Pronounced ecophysiological clonal differences of two common freshwater ciliates, Coleps spetai (Prostomatida) and Rimostrombidium lacustris (Oligotrichida), challenge the morphospecies concept. J Plankton Res 27:55-63

Weisse T, Stadler P (2006) Effect of pH on growth, cell volume, and production of freshwater ciliates, and implications for their distribution. Limnol Oceanogr 51: 1708-1715

Weisse T, Karstens N, Meyer VCM, Janke L, Lettner S, Teichgräber K (2001) Niche separation in common prostome freshwater ciliates: the effect of food and temperature. Aquat Microb Ecol 26:167-179

Zar JH (1984) Biostatistical analysis. Prentice-Hall, Englewood Cliffs, NJ

Submitted: June 30, 2006; Accepted: September 11, 2006 Proofs received from author(s): December 18, 2006 